(2) norden 



\section{Förpackningar för alla - Packages for all}


Förpackningar för alla - Packages for all

TemaNord 2007:551

(C) Nordiska ministerrådet, Köpenhamn 2007

ISBN 978-92-893-1530-2

Tryckt på miljövänligt papper som uppfyller kraven i den nordiska miljösvanemärkningen. Publikationen kan beställas på www.norden.org/order. Fler publikationer på www.norden.org/publikationer

Nordiska ministerrådet Store Strandstræde 18 DK-1255 Köpenhamn K Telefon (+45) 33960200 Fax (+45) 33960202

www.norden.org

\section{Nordiska rådet}

Store Strandstræde 18

DK-1255 Köpenhamn K

Telefon (+45) 33960400

Fax (+45) 33111870

\section{Det nordiska samarbetet}

Det nordiska samarbetet är ett av världens mest omfattande regionala samarbeten. Det omfattar Danmark, Finland, Island, Norge och Sverige samt de självstyrande områdena Färöarna, Grönland och Åland.

Det nordiska samarbetet är politiskt, ekonomiskt och kulturellt förankrat och är en viktig partner i europeiskt och internationellt samarbete. Den nordiska gemenskapen arbetar för ett starkt Norden i ett starkt Europa.

Det nordiska samarbetet vill styrka nordiska och regionala intressen och värderingar i en global omvärld. Gemensamma värderingar länderna emellan bidrar till att stärka Nordens ställning som en av världens mest innovativa och konkurrenskraftiga regioner. 


\section{Innehållsförteckning}

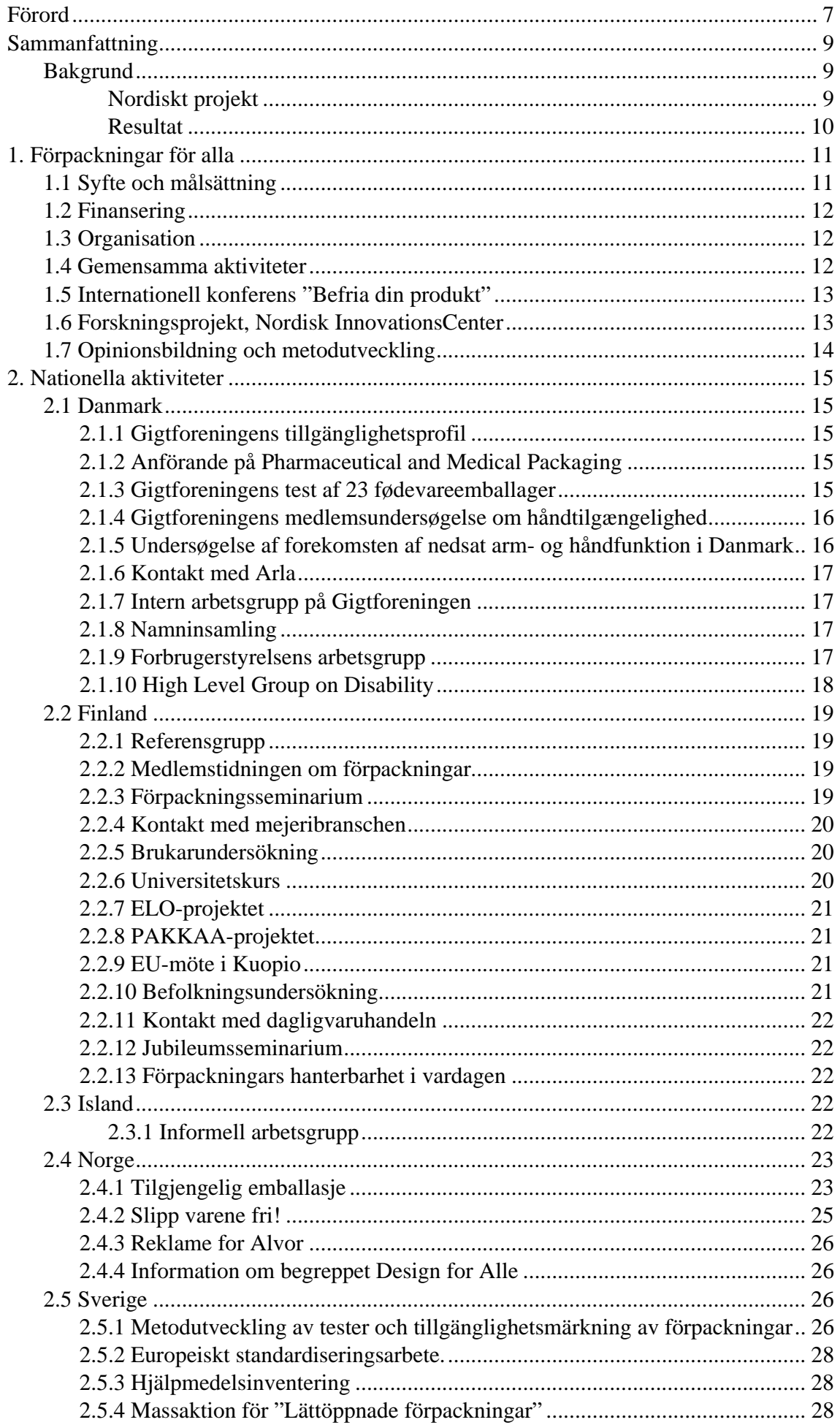


2.5.5 Folkrörelseprojektet "Lättöppnade förpackningar”

2.5.6 Samarbete med olika designutbildningar ................................................29

2.5.7 Utbildning av testkonsulenter för tillgänglighetsvärdering ........................... 30

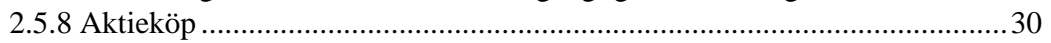



3.1 Fortsatt samarbete ......................................................................................... 31

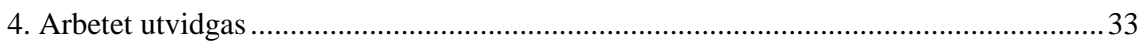

4.1 Etablera brukarpaneler utifrån visionen Design för Alla........................................ 33 


\section{Förord}

I de nordiska länderna finns 3-4 miljoner konsumenter med nedsatt handfunktion. Gruppen ökar i takt med att befolkningen blir allt äldre. Varje dag möter många av dem, och många fler, problem vid hanteringen av förpackningar för dagligvaror, läkemedel, hälsokost med flera produkter.

I Sverige påbörjade Reumatikerförbundet 2003 ett arbete för att få till stånd en utveckling av förpackningarna som tar sin utgångspunkt i konsumenternas krav på hanterbara förpackningar. Det skedde i samarbete med företag, branschorganisationer och myndigheter. Metoder för bedömning av förpackningars tillgänglighet/användbarhet vid nedsatt handfunktion utvecklades. Opinionsbildning i samarbete med pensionärsorganisationer, handikapprörelsen och Sveriges Konsumenter startade.

Med stöd av medel från styrgruppen för produktfrågor inom Nordiska Ministerrådet genomfördes det nordiska projektet "Förpackningar för alla - Packages for all” 2004-2006.

Projektet har syftat till att etablera samarbete i Norden för att marknaden ska erbjuda konsumenterna förpackningar som är lätta att hantera. 



\title{
Sammanfattning
}

\author{
Bakgrund
}

Reumatikerförbundet i Sverige genomförde 2003 en förstudie om förutsättningarna att påverka framtida utformningen av läkemedelsförpackningar. Under 2004 genomförde Reumatikerförbundet en större konsumentaktion i Sverige som uppmärksammade bra och dåliga förpackningar inom dagligvaruhandeln. Samarbete etablerades med Handikappförbundens Samarbetsorgan och de två stora pensionärsorganisationerna PRO och SPF samt Sveriges Konsumenter (tidigare Sveriges Konsumentråd).

En metod att med brukare och industridesigner testa och utveckla lättöppnade och lätthanterliga förpackningar utvecklades under Reumatikerförbundets ledning i samarbete med Unicum, Nordisk Design för Alla Center och Spenshult AB. Samarbete med förpackningsindustri och företag startade.

Referensgrupp i metodutvecklingsarbetet var Läkemedelsverket, Läkemedelsförmånsnämnden, Apoteket, Läkemedelsindustriföreningen, Konsumentverket, Dagligvaruhandelns Leverantörsförbund och Hälsokostrådet.

\section{Nordiskt projekt}

I samarbete mellan de Nordiska ländernas reumatikerorganisationer och svenska partners ansöktes och erhölls medel under 2004/2005 och 2005/2006 från Nordiska Ministerrådet till vårt konsumentpolitiska projekt.

Projektets kortsiktiga målsättning:

- Etablera en nordisk projektgrupp och nationella referensgrupper som verkar för mer tillgängliga förpackningar på marknaden

- Sprida kunskap om det utvecklingsarbete som genomförs i Sverige samt ta del av övriga länders erfarenheter

- I samarbete med myndigheter och handelns branschorganisationer genomföra minst en heldagskonferens i Stockholm/Köpenhamn under 2005 med tema Förpackningar för alla.

Projektets syfte:

- Skapa bärare av arbetet/visionen i varje nordiskt land

- Utbyta kunskap och erfarenheter inom Norden

- Öka det nordiska samarbetet avseende utveckling av förpackningar 
- Utgöra nordisk forum vid framtagande av riktlinjer/standarder för förpackningar, med inriktning mot Design för alla, och som

komplement till CEN/CENELEC Guide 6 (ISO/IEC Guide71).

\section{Resultat}

Nordisk projektgrupp med representanter för reumatikerorganisationerna har lett arbetet. En nordisk intressentgrupp/nätverk med representanter för konsumentorganisationer, branschorganisationer, myndighetsanknutna organ och forskningsinstitut har etablerats. En nordisk konferens "Befria din produkt” genomfördes i Stockholm den 5 maj 2006 med 150 deltagare. Se www.befriadinprodukt.se

Mer omfattande verksamheter och projekt är etablerade i Sverige, Danmark och Finland genom reumatikerorganisationerna där.

Ett europeiskt standardiseringsarbete med nationella arbetsgrupper i varje land arbetar nu med att ta fram en standard för lättöppnade förpackningar med den svenska testmetoden som grund.

Förutsättningarna för att nå syftet att marknaden ska erbjuda konsumenterna lättöppnade förpackningar är goda. Både produkter och marknadsföring visar att företag har ökat fokus på denna fråga. 


\section{Förpackningar för alla}

\subsection{Syfte och målsättning}

Reumatikerförbundet i Sverige startade 2004, med stöd av Allmänna Arvsfonden det bredare folkrörelseprojektet "Lättöppnade förpackningar" i samarbete med PRO, Pensionärernas Riksorganisation, SPF, Sveriges Pensionärsförbund, HSO, Handikappförbundens Samarbetsorgan och Sveriges Konsumenter (f.d. Sveriges Konsumentråd). Då fanns också en uttalad målsättning att engagera övriga nordiska länder i arbetet.

Företagens produkter måste kunna ha avsättning på betydligt större marknader än de nationella. Genom att mobilisera konsumenter i hela Norden kan företagen påverkas lättare. Med ökat konsumenttryck kommer förpackningsindustrin lägga ökat fokus på detta område vid utveckling av nya produkter. Varumärkesägare som inser att lätthanterliga förpackningar kan bli en viktigare konkurrensfaktor integrerar denna del i sin produktutveckling. För företag i Norden innebär det en möjlighet att kunna leda utvecklingen inom området och stärka sin marknadsposition även på de Europeiska och globala marknaderna.

Syftet med projektet är:

- att skapa bärare av arbetet/visionen i varje nordiskt land

- att utbyta kunskap och erfarenheter inom Norden

- att öka det nordiska samarbetet avseende utveckling av förpackningar

- att utgöra nordiskt forum för framtagande av riktlinjer/standarder för förpackningar med inriktning mot Design för Alla och som komplement till CEN/CENELEC Guide 6 (ISO/IEC Guide 71).

De långsiktiga målsättningarna för projektet är:

- att etablera en gemensam värderingsmetod och en standard för tillgängliga förpackningar

- att erbjuda nordiska företag en konkurrensfördel genom att tillhandahålla stöd i utvecklingen av förpackningar som är tillgängliga för alla människor

- att erbjuda konsumenter i Norden ett utbud av produkter med förpackningar som enkelt går att öppna, dosera och återförsluta. 


\subsection{Finansering}

Projektet har haft en omsättning på 724000 Dkr. Genom Nordiska Ministerrådets styrgrupp för Produktfrågor erhöll projektet 2005 och 2006 402500 Dkr. SP (numera Sveriges Tekniska Forskningsinstitut) har bidragit med 16400 Dkr, Reumatikerförbundet i Sverige 77800 Dkr, Den Nordiska konferensen erhöll branschstöd om 82100 Dkr, deltagarintäkter om 86200 Dkr och Reuma Utveckling AB svarade för 60000 Dkr.

\subsection{Organisation}

Reumatikerförbundet i Sverige har varit huvudman för projektet. En nordisk arbetsgrupp har utgjort ledningsgrupp. I arbetsgruppen ingår representanter för Reumatikerförbundet i Sverige, Gigtforeningen i Danmark, Reumaförbundet i Finland, Norsk Revmatikerforbund och Gigtarfélag Ísland.

En nordisk intressentgrupp/nätverk har bildats för att förankra arbetet. I den nordiska intressentgruppen ingår representanter från olika organisationer med intresse för förpackningsfrågor. Från Sverige deltar Reumatikerförbundet, SP, Sveriges Tekniska Forskningsinstitut och LIF, Läkemedelsindustriföreningen. Från Norge deltar Den Norske Emballasjeforening, Funktionshemmedes Fellesorganisation, Norsk Designråd och Deltasenteret. Från Finland deltar TTS-institutet, STAKES Forskningsoch utvecklingscentralen för social- och hälsovården och Stora Enso Packaging. Från Danmark deltar Ældremobilisering och Forbrugerstyrelsen.

Genom denna sammansättning finns olika konsumentorganisationer, branschorganisationer, myndighetsanknutna institutioner och forskningsoch utvecklingscentra i de nordiska länderna representerade.

Arbetet inom projektet "Förpackningar för alla” har omfattat både gemensamma aktiviteter på nordisk nivå, nationella projekt och opinionsbildning samt medverkan i produktutveckling i några länder.

\subsection{Gemensamma aktiviteter}

De gemensamma aktiviteterna har utöver intressentgruppens möten omfattat anordnandet av en internationell konferens och en forskningsansökan till Nordisk InnovationCenter, NIC. Därutöver har ledningsgrupp och intressentgrupp medverkat med information om och stöd till projekt och projektansökningar i flera nordiska länder. Vi har också agerat för skärpning av lagstiftning kring offentlig upphandling med inriktning mot Design för Alla. 


\subsection{Internationell konferens "Befria din produkt”}

Den 5 maj 2006 anordnades i Stockholm en mycket välbesökt och uppskattad internationell konferens, "Befria din produkt". Den samlade ca 150 deltagare från myndigheter, företag, organisationer och designers. Dokumentation från konferensen utgör en huvudprodukt i projektet och har tidigare redovisats till Nordiska Ministerrådet i tryckt version. Den kan också laddas ner från Internet:

http://www.befriadinprodukt.se/fileserver/Befria_din_produkt_dokument ation_061115_skarm.pdf

\subsection{Forskningsprojekt, Nordisk InnovationsCenter}

SP Sveriges Tekniska Forskningsinstitut ansvarar för ett forskningsprojekt med stöd av Nordisk InnovationsCenter. Projektet syftar till att på vetenskaplig grund skapa en internationellt standardiserad metod för tillgänglighetsprovning och som kan tillämpas på ett brett spektrum av olika förpackningar.

Som medsökande i projektet finns också från Sverige SIK Institutet för Livsmedel och Bioteknik, Spenshults Reumatikersjukhus, Cerbo och Reumatikerförbundet. Från Danmark deltar Teknologisk Institut och Emballage og Transports Medlemskreds. Från Finland deltar VTT Statens Tekniska Forskningscentral, Pakkausteknologia PTR-ry, (The Finnish Association of Packaging Technology and Research), Design for Allnätverket/Forsknings- och utvecklingscentralen för social- och hälsovården (STAKES), Stora Enso Packaging och Reumaförbundet i Finland. Från Norge deltar Den Norske Emballasjeforening.

Projektet är uppdelat i två faser.

Mål för fas 1 är:

- att skapa en struktur/kategorisering av olika förpackningstyper med avseende på tillgänglighetsaspekter

- att kartlägga/kategorisera potentiella brukarsegment med avseende på fysiska förutsättningar och förmåga

- att identifiera de mest relevanta mätmetoderna som har förutsättningar att utgöra basen för den slutliga tillgänglighetsprovningsmetoden

- att informera, intressera och involvera nordiska företag i utvecklingsarbetet. 
Mål för fas 2 är:

- att skapa det vetenskapliga underlaget för utveckling av tillgänglighetsprovningsmetoden.

Anslag om 1500000 Nkr beviljades den våren 2006. Fas 1 beräknas vara avslutad den 30 april 2007 och fas 2 den 2 september 2008.

\subsection{Opinionsbildning och metodutveckling}

I alla de nordiska länderna utom Island har det pågått ett arbete som syftat till att skapa en högre medvetenhet och starkare opinion för mer lättöppnade förpackningar. Det finns också exempel på utarbetande av metoder för hur redan existerande förpackningar ska bedömas och vilka krav som ska ställas vid framtagande av nya förpackningar. 


\section{Nationella aktiviteter}

\subsection{Danmark}

\subsubsection{Gigtforeningens tillgänglighetsprofil}

I Gigtforeningens Tilgænglighedsprofil finns ett avsnitt som handlar om Detail- og medicinemballage: "mennesker med muskel- og skeletsygdomme skal kunne håndtere detail- og medicinemballage uden brug af særlige hjælpmidler eller hjælp fra andre”. Där ställs krav på riktlinjer för hur medicinförpackningar respektive dagligvaru-förpackningar ska utformas för att bli mer lättillgängliga.

\subsubsection{Anförande på Pharmaceutical and Medical Packaging}

I samband med den årliga konferensen, Pharmaceutical and Medical Packaging, höll Gigtforeningens direktör Lene Witte ett anförande på 2004 års konferens om förpackningar och deras tillgänglighet, "Hvorfor skal det være så svært?”.

Efter denna konferens skrev Gigtforeningen en artikel om frågan som publicerades i olika tidskrifter, bland annat i marsnumret 2005 av PackMarkedet, en tidning som vänder sig till förpackningsproducenter och designers.

http://www.gigtforeningen.dk/maerkesager/tilgaengelighed/packmarkedet

Gigtforeningen medverkar också i 2007 års konferens.

\subsubsection{Gigtforeningens test af 23 fødevareemballager}

2005 gjorde Gigtforeningen en kvalitativ test av hur tillgängliga och lättöppnade ett antal typiska produkter på det danska frukostbordet är. Syftet med testet var att utveckla en metod som kan ligga till grund för utveckling av en standard för lättöppnade förpackningar.

Huvudresultaten av undersökningen är:

- Det är inte bara människor som är handsvaga som har problem med att öppna förpackningar.

- Det finns förpackningar som är lättillgängliga. 
- Dåliga förpackningar har små flärpar och kräver stor styrka för att kunna öppnas.

Undersökningen presenterades i juni 2005. Gigtforeningen inbjöd därefter den dåvarande forbrugerministern Lars Barfoed till en brunch där ett antal frukostprodukter presenterades och där han fick möjlighet att pröva på att öppna dem.

http://www.gigtforeningen.dk/14A39F30-CD21-44F5-96EA7B77EB164E89

\subsubsection{Gigtforeningens medlemsundersøgelse om håndtilgcengelighed}

I medlemstidningen Ledsager $\mathrm{nr}$ 5/2005 fanns ett formulär med frågor om vilka besvär medlemmarna har vid hantering av förpackningar.

Föreningen fick in 1200 svarsformulär. 93 procent av dem kom från kvinnor, företrädesvis över 45 år, de flesta mellan 55 och 75 år. 98 procent av dem som besvarade enkäten uppger att de har problem med att öppna förpackningar. 33 procent har problem varje dag, 59 procent flera gånger i veckan. 80 procent uppger att de måste använda hjälpmedel, till exempel sax. 90 procent ber andra om hjälp. 68 procent uppger att de är villiga att betala en krona mer för en tillgänglig förpackning.

Resultatet presenterades i nr 1/2006 av Ledsager. http://www.gigtforeningen.dk/C4506698-A495-4A8B-A0B0$\underline{\mathrm{D} 48773 \mathrm{D} 6 \mathrm{C} 888}$

\subsubsection{Undersøgelse af forekomsten af nedsat arm- og håndfunktion $i$} Danmark

Undersökningen är gjord som en intervjuundersökning av ett statistiskt urval av den danska befolkningen över 18 år. Totalt har ca 1500 personer tillfrågats. Resultatet, som presenterades i maj 2006, visar att 16,8 procent av befolkningen uppger att de under det senaste året haft besvär med att använda händer och armar. 8 procent har dagligen besvär med sina händer.

Den grupp som upplever att de har störst besvär är kvinnor, där 22 procent anger att de har haft besvär med händer och armar det senaste året och särskilt då kvinnor över 45 år. I gruppen kvinnor över 65 år är det 16 procent som har dagliga besvär med sina händer. http://www.gigtforeningen.dk/E1DA421E-FEBC-46FE-8B3D-

\section{C918363BB6EA}




\subsubsection{Kontakt med Arla}

I en artikel i BT den 30 april 2006 kritiserade Gigtforeningen Arlas nya yoghurtförpackning med skruvlock. Den är besvärlig att öppna för barn, äldre och handsvaga och den är besvärlig att tömma och pressa ihop när den ska till återvinningen. Det ledde till att Arlas marknadschef Jesper Friis Sørensen besökte Gigtforeningen och fick en lektion i tillgänglighet och i vilka svagheter de nuvarande förpackningarna har. Arla har därefter tillsatt en projektgrupp för att utveckla en nordisk förpackningsstrategi. En av gruppens uppgifter är att ta tillvara speciella gruppers behov.

\subsubsection{Intern arbetsgrupp på Gigtforeningen}

Inom Gigtforeningen finns en intern arbetsgrupp som består av en arbetsterapeut, en sjukgymnast och en reumatiker. En av arbetsgruppens arbetsuppgifter är att arbeta med medicin- och detaljhandelsförpack-ningar. Föreningen planerar att göra en undersökning av medicin-förpackningar, kontakt kommer då att tas med läkemedelsstyrelsen.

\subsubsection{Namninsamling}

Gigtforeningen har startat en namninsamling som kräver bättre förpackningar på sin hemsida. De insamlade namnen överlämnas till forbrugerminister Carina Christensen på den internationella reumatikerdagen den 12 oktober 2007.

\subsubsection{Forbrugerstyrelsens arbetsgrupp}

Efter brunchen hos Gigtforeningen inbjöds den dåvarande forbrugermi nistern Lars Barfoed ett antal berörda organisationer till en dialog kring de problem som han hade förstått fanns med förpackningar. De organisationer som inbjöds var Design for Alle, Dansk Design Center, Center for Ligebehandling af Handicappede, Foreningen af Danske Designere, IDForum, Gigtforeningen, De Samvirkende Invalideorganisationer, Emballageindustrien, Plastindustrien, Fødevareindustrien / DI och DagSam (DLF).

Efter det första mötet fanns enighet i gruppen om att jobba vidare tillsammans. Forbrugerstyrelsen fick i uppdrag att undersöka frågan närmare och inbjöd därför till ett andra möte som utmynnade i bildandet av en arbetsgrupp som bestod av de inbjudna organisationerna. Gruppens övergripande uppgift är att arbeta för tillgänglighet för brukarna och att öka näringslivets konkurrensförmåga inom området. Den sorterar under Forbrugerstyrelsen, vars vice direktör Mogens Hansen är ordförande i gruppen. 
Förutom arbetsgruppen har också en styrgrupp bildats. I den ingår samma organisationer som i arbetsgruppen, förutom representanten för ministeriet för Familie- og Forbrugerlanliggender, som enbart ingår i arbetsgruppen. En skillnad mellan grupperna är att organisationerna inte alltid är representerade av samma personer.

Enligt förpackningsindustrins representanter finns bra lösningar, problemet är bara att de inte tillämpas. Gruppens uppfattning är därför att det inte finns behov av att utarbeta standarder för hur förpackningar ska se ut. Fokus i arbetsgruppen ligger på den fysiska tillgängligheten till förpackningar, inte hjälpmedel.

Forbrugerstyrelsen håller f.n. på att ta fram målformuleringar för gruppens arbete. Detta förslag skickas inom kort ut till medlemmarna i arbetsgruppen för synpunkter.

Gruppen har fått i uppgift att dels göra en kartläggning av vad som gjorts inom förpackningsområdet i Danmark fram till nu, dels ta fram positiva exempel på hur förpackningsfrågan kan hanteras i praktiken, s.k. business-cases. De kan ha tre olika utformningar:

1. Beskrivning av redan genomförda projekt som är bra exempel eller som är exempel på en fungerande utvecklingsväg.

2. Genomföra en process i ett eller flera projekt på ett eller flera företag.

3. Uppmärksamma ett väl genomfört projekt med ett pris.

Forbrugerstyrelsen har utarbetat ett anbudsunderlag som skickades ut under december 2006 med en förfrågan om framtagande av underlag för att kunna utföra detta uppdrag. I februari räknar man med att fatta beslut om vem som får uppdraget. Forbrugerstyrelsen har avsatt 50000 dkr. för detta.

\subsubsection{High Level Group on Disability}

Den förre forbrugerministern Lars Barfoed har skickat en skrivelse till sin kollega social- och jämställdhetsminister Eva Kjær Hansen med önskemål om att hon ska ta upp frågan om tillgänglighet för fysiska produkter på dagordningen inom High Level Group on Disability, den grupp inom EU som bland annat har ansvar för The European Action Plan: Equal opportunities for people with disabilities.

Skrivelsen sändes ut till ledamöterna i High Level Group on Disability inför gruppens möte i oktober. Gruppen hann inte diskutera skrivelsen på sitt oktobermöte, utan beslöt att ägna sitt nästa möte i februari 2007 åt Design för Alla, och i första hand förpackningars tillgänglighet. 


\subsection{Finland}

\subsubsection{Referensgrupp}

På initiativ av Reumaförbundet i Finland rf etablerades hösten 2005 en referensgrupp. Den hade sitt första möte den 31/8 2005 då 17 personer deltog. I gruppen ingår representanter för Statens tekniska forskningscentral (VTT), TTS-institutet (Department of Home Economics), Design for All-nätverket/Forsknings- och utvecklingscentralen för social- och hälsovården (STAKES), Förpackningsteknologiföreningen-PTR rf (The Finnish Association of Packaging Technology and Research), Social- och hälsovårdsministeriet, Lääketeollisuus ry (Läkemedelsindustrin rf), Handels- och industriministeriet, Teknologiska utvecklingscentralen (TEKES), Borgå Reumaförening, Kuluttajatutkimuskeskus (Konsumentforskningscentralen), Päivittäistavarakauppa ry (Dagligvaru-handeln rf), Reumaliiton Kuntoutumiskeskus Apila (Reumaföbundets Rehabiliteringscenter Apila) och Stora Enso Packaging.

Syftet med etablerandet av gruppen är att samla aktörer som på olika sätt är engagerade i förpackningsfrågan och försöka få dem att jobba med den inom sina respektive organisationer. Den är ett sätt att sprida idén om behovet av lättöppnade förpackningar. Sedan start har referensgruppen träffats fyra gånger. Den fortsätter att träffas kontinuerligt.

\subsubsection{Medlemstidningen om förpackningar}

Hösten 2005 skrev Reumaförbundets medlemstidning om förpackningar.

\subsubsection{Förpackningsseminarium}

På den internationella Reumadagen 12/10 2005 anordnade Förpackningsteknologiföreningen tillsammans med TEKES seminariet "Information och säkerhet för förpackningar” där också förpackningars öppningsbarhet ingick. Reumaförbundet i Finland ansvarade för den del av seminariet som handlade om lättöppnade förpackningar. Följande anföranden hölls om förpackningar:

- Tita Ström, Reumaförbundet i Finland, Nordiskt förpackningsprojekt sätts igång i Finland.

- Päivi Tahkokallio, Design for all/Forsknings- och utvecklingscentralen för social- och hälsovården (STAKES), Design for All - bättre kvalité för alla?

- Noora Nylander, Stora Enso Packaging, New Business Innovation, Designing from packaging producers point of view - Designing easy opening solutions, a case study. 
Seminariet samlade 150 deltagare från förpackningsbranschen och fick stor publicitet i media.

\subsubsection{Kontakt med mejeribranschen}

Seija Kaustinen, verkställande direktör på Kaustisten Meijeri, kontaktade Reumaförbundet i december 2005 för att presentera nya mjölkförpackningar med skruvlock. Förbundet bedömde att dessa förpackningar var mycket bra ur hanterbarhetssynpunkt. Förpackningarna har på prov sålts i Södra Savox.

Seija Kaustinen planerade att därefter kontakta Ingman Foods i förhoppning om att företaget skulle vara intresserat av kontakt med Reumaförbundet i frågan. Det är osäkert vad som har hänt. Reumaförbundet planerar att kontakta Ingman Foods för en fortsatt diskussion.

\subsubsection{Brukarundersökning}

Reumaförbundet har träffat ett avtal med läkemedelsföretaget Abbott Oy som innebär att förbundet kan engagera designföretaget Next Icon Design för att göra en brukarundersökning av olika förpackningar som används i vardagen. Syftet med projektet är att fler ska få upp ögonen för vikten av lättöppnade förpackningar överhuvudtaget, inte enbart medicinförpackningar.

Abbott Oy, ett företag som tillverkar mediciner för människor med reumatiska sjukdomar, gör denna satsning för att stärka sitt varumärke i patientgruppen och i viss mån ge tillbaka en del av sin vinst. Företaget ställer inga krav på vilka förpackningar som ska undersökas utan det bestäms gemensamt av Reumaförbundet och Next Icon Design. Reumaförbundet ansvarar för information om problemen, planerar testningen och väljer ut de personer som ska delta.

Undersökningen genomfördes hösten 2006 och resultatet publicerades den 24 januari 2007,

http://www.nexticon.fi/ETU/NEXTICON_ETU_kayttajatutkimus_tuloks et.pdf. Publiceringen har redan resulterat i företagssamarbete.

\subsubsection{Universitetskurs}

Stora Enso har beställt en ettårig produktutvecklingskurs, "Lättöppnade förpackningar, Product Development Project” av Tekniska högskolan i Helsingfors. Övriga samarbetspartners är Reumaförbundet, Konstindustriella högskolan och Tekniska Högskolan i Tallinn. Kursen, som har samlat tio deltagare, utgår från en produkt som har haft samma utformning i 30 år. Den startade i oktober 2006 och avslutas i april 2007. Om det kommer att bli en fortsättning är i nuläget osäkert. 


\subsubsection{ELO-projektet}

Livsmedelsföretaget Raisio Group har startat ett projekt, kallat ELOprojektet, som omfattar produktutveckling och formgivning av förpackningar för hälsosamma mejeriprodukter, s.k. functional food (mervärdesmat). Raisio Group samarbetar i projektet med formgivarna och forskarna Pinja Rojo och Satu Typpo från Konstindustriella högskolan. Projektet har fått ekonomiskt stöd från Sitra, en fond som stödjer forskning som syftar till att utveckla det ekonomiska välståndet i Finland.

Syftet med ELO-projektet, som vänder sig till 55+, är att förstå hur förpackningar används och att på denna grund ta fram förpackningar som är mer brukarvänliga. Reumaförbundets ansvar i projektet är att ta fram lämpliga testpersoner. Projektet pågår under ett år och är ännu inte avslutat.

\subsubsection{PAKKAA-projektet}

Reumaförbundet har i samarbete med referensgruppen sökt och erhållit medel från Penningautomatföreningen för ett flerårigt projekt som syftar till att väcka den allmänna opinionen för behovet av mer lättöppnade förpackningar, PAKKAA-projektet. I projektet ingår att bilda lokala arbetsgrupper tillsammans med olika samarbetspartners såsom pensionärsorganisationer, konsumentorganisationer och handikapporganistioner.

Syftet med projektet är att i första hand påverka handeln och förpackningsindustrins representanter och formgivare. Målet är att i framtiden kunna erbjuda folket dagligvaru- och läkemedelsförpackningar som är lättare att öppna och använda än dagens.

Reumaförbundet har fått 80000 euro för år 2007. Projektet pågår under tre år.

\subsubsection{EU-möte i Kuopio}

Vid EU-mötet den 20-21 september 2006 i Kuopio anordnades ett Health in All Politics Seminar för representanter från EU-ländernas ministerier. Då presenterades fyra finska projekt, ett av dem var Reumaförbundets förpackningsprojekt. Inför presentationen producerade Reumaförbundet en informationsbroschyr, ETU - Easy to Use Packaging, som utformades av grafiker Pekka Loiri.

\subsubsection{Befolkningsundersökning}

År 2000 gjordes en stor undersökning av den finska befolkningens hälsotillstånd genom ett representativt urval. I undersökningen ställdes också frågor om hur många som har problem med händerna i sin vardag. Denna del av undersökningen är ännu inte sammanställd. För att diskutera möj- 
ligheten att kunna göra en sådan sammanställning kontaktade Reumaförbundet i februari 2006 överläkare Markku Heliövaara på Folkhälsoinstitutet. Reumaförbundet försöker få den finansierad genom PAKKAAprojektet eftersom en sådan sammanställning skulle vara mycket värdefull inför det fortsatta arbetet.

\subsubsection{Kontakt med dagligvaruhandeln}

Reumaförbundet har sökt kontakt med dagligvaruhandeln för att undersöka deras intresse för mer lättöppnade förpackningar för deras egna varumärken. Det finns för närvarande inget intresse från branschen för frågan.

\subsubsection{Jubileumsseminarium}

Med anledning av att Reumaförbundet fyller 60 år anordnas under hösten 2007 ett jubileumsseminarium. Temat för seminariet kommer att vara förpackningar.

\subsubsection{Förpackningars hanterbarhet $i$ vardagen}

TTS-institutet (Department of Home Economics) har i samarbete med Hushållslärarutbildningen sökt ekonomiskt stöd från Wihuri Stiftelsen för projektet "Förpackningars hanterbarhet i vardagen".

Projektet är upplagt i tre steg:

Steg 1: Ett antal hushåll för dagbok och fotograferar de olika förpackningar som de vanligen använder.

Steg 2: Av de erfarenheter som görs i hushållen väljs de besvärligaste förpackningarna ut för att testas i Hushållslärarutbildningens laboratorium.

Steg 3: Testning i hushåll och i laboratoriemiljö av hjälpmedel som man använder för att öppna förpackningar.

Ansökan har avslagits, men ny ansökan kommer att utarbetas.

\subsection{Island}

\subsubsection{Informell arbetsgrupp}

Gigtarfélag Ísland har följt frågan men ej genomfört särskilda aktiviteter inom projektet. 


\subsection{Norge}

\subsubsection{Tilgjengelig emballasje}

Norsk Designråd har i samarbete med Deltasenteret och Norsk Revmatikerforbund genomfört ett pilotprojekt inom området lättöppnade förpackningar för dagligvaruhandeln, "Tilgjengelig emballasje, dagligvareprodukter”. Deltagande designföretag har varit KODE Design.

Syftet med förstudien var att etablera ett norskt projekt som ska arbeta för utveckling av mer brukarvänliga förpackningar med utgångspunkt i Design för Alla. Det finns i projektet en tydlig ambition att påvisa lönsamheten med användandet av ett Design för Alla-perspektiv. http://www.norskdesign.no/aktiviteter/designforalle/0602-

10tilgjengeligemballasje.pdf

Med utgångspunkt i resultatet av förstudien delades projektet upp i två delar:

1. En generell brukarstudie och värdering av förpackningar utifrån

Design för Alla-perspektiv, "Fra barriere til innovasjon".

2. Ett pilotprojekt med ett producerande företag.

Rapporten från del 1 , den generella brukarstudien, omfattar dels några generella råd när det gäller lättöppnade förpackningar som är baserade på användarstudier som gjorts av vanliga förpackningar inom dagligvaruhandeln, dels problem som olika kundgrupper har i förhållande till förpackningar.

Brukarstudien har genomförts i två omgångar. I den första undersöktes 70 förpackningar för att därigenom ta reda på om det fanns några gemensamma nämnare när det gäller bra och dåliga förpackningar. Därefter utvecklades principlösningar som innebar en ökad tillgänglighet för den aktuella förpackningen. I den andra undersöktes dessa principlösningar.

De 7 principer som ingår i begreppet Design för Alla är:

1. Lika möjligheter för användning.

2. Flexibel användning.

3. Enkel och intuitiv användning.

4. Begriplig information

5. Tolerans vid felanvändning.

6. Låg fysisk ansträngning.

7. Storlek och utrymme för åtkomst och hantering.

Den teoretiska modell som projektet har utgått från omfattar:

1. Hur förpackningen kommunicerar. 
2. Användarnas reflektion och förståelse av förpackningen.

3. Användarnas handlande.

De Design för Alla-kriterier som undersökningen bygger på är:

- att köpa och välja

- användning

- lagring

- beredning och konsumtion

- kassering.

Under varje kriterium fanns sedan ett antal delfrågor som brukarna fick besvara utifrån en skala från 1 till 7, där 1 var sämst och 7 bäst.

$0=$ ej relevant

$1=$ omöjligt

2 = mycket besvärligt, mycket stort behov av förändringar

3 = besvärlig, stort behov av förändringar

4 = irriterande, möjlig att förändra

$5=$ bra

6 = bra, men den går att förbättra

7 = bra, behöver inte förbättras

Vid värdering av en förpackning utifrån dessa kriterier görs en samlad bedömning som också tar hänsyn till de olika målgrupperna. En förpackning som är bra ur Design för Alla-synpunkt ska inte bara vara lätt att öppna, den ska också synas i butiken så att det är möjligt för konsumenten att göra ett bra val.

70 förpackningar undersöktes av s.k. elitanvändare, som i det här fallet var reumatiker, äldre, synsvaga och barn. Som kontrollgrupp användes normalanvändare. De krav som de olika grupperna ställer på en lättöppnad förpackning skiljer sig åt.

Resultat från test av reumatiker:

- stora flärpar

- stora skruvkorkar

- räfflor, gripvänliga material

- möjlighet att ta ett alternativt grepp.

Resultat från test av äldre:

- de har svårt för att förstå nya användningssätt

- om öppningen inte verkar enkel, använder de sax

- låg medvetenhet om produktvarianter

- köper välkända produkter, frestas sällan att pröva nya

- har dålig finmotorik och begränsad smidighet. 
Resultat från test av synsvaga:

- det vore en fördel om varorna hade bestämda platser i alla affärer

- störtexponering fungerar inte för varor som normalt står i ögonhöjd, synsvaga letar alltid efter varor i ögonhöjd

- starka färger syns bäst, särskilt gult, svart och rött, men också skarpa kontraster mellan mörka och ljusa färger

- det är viktigt med stora bokstäver

- synsvaga letar sig fram till rätt vara i hyllan

- varor kan visuellt försvinna av andra varor som står i närheten

- öppningarna bör vara visuellt tydliga, till exempel genom kontrast

- synsvaga ska kunna känna rivkanten

- använder känseln för att hitta svagheter i förpackningen.

Resultat från test av barn:

- många förpackningsöppningar är nya och kan inte förstås intuitivt

- tror ofta att de inte kan

- bör kräva lite styrka

- flärpar är enkla

- varorna ska vara möjliga att öppna utan att man spiller

- barn är ovana och användningen ska inte kräva precision

- tycker om att klara sig själva.

Resultat från test av normalgruppen:

- otålighet leder till att man river upp på fel sätt

- använder ofta sax

- förpackningar i starka färger är inte alltid lockande

- tar sig sällan tid att läsa på förpackningen om hur den ska öppnas

- läser aldrig kontrollinformationen på baksidan.

http://www.norskdesign.no/aktiviteter/designforalle/frabarrieretilinnovasj on-rapport.pdf

Del 2 är en konfidentiell rapport av det projekt som KODE Design genomfört tillsammans med Jordan utifrån det Design för Alla-perspektiv som utarbetades i del 1.

\subsubsection{Slipp varene fri!}

Norsk Revmatikerforbund har sökt pengar från Helse- og Rehabilitering till projektet "Slipp varene fri”. Det är en fortsättning på projektet "Tilgjengelig emballasje" och syftar till att föra ut de erfarenheter som gjordes där. Projektet planerades att genomföras i samarbete med Norsk Designråd och Deltasenteret. Det finns för närvarande inga ekonomiska medel 
för att kunna starta projektet. Norsk Revmatikerforbund planerar att söka pengar för projektet inför 2008.

\subsubsection{Reklame for Alvor}

Varje år får en ideell organisation en chans att få en gratis kampanj från reklambranschen för ett specifikt ändamål. Den kallas Reklame for Alvor och Revmatikerforbundet ansökte om medel 2006. Ansökan blev inte beviljad.

\subsubsection{Information om begreppet Design for Alle}

En av Norsk Designråds uppgifter är att sprida information kring begreppet Design for Alle.

Ett exempel på det är det föredrag som projektledaren för programmet Innovasjon for alle Onny Eikhaug höll i Lilleström i februari 2006: ”Design for alle - hvad innebærer det i et emballasjeperspektiv. Om potentialen att utveckla användarvänliga förpackningar”. http://www.norskdesign.no/aktiviteter/designforalle/frabarrieretilinnovasj on-rapport.pdf

\subsection{Sverige}

\subsubsection{Metodutveckling av tester och tillgänglighetsmärkning av förpackningar}

2003 gjorde Reumatikerförbundet tillsammans Apoteket, Hjälpmedelsinstitutet och Läkemedelsindustriföreningen en förstudie för att undersöka förutsättningarna för att påverka den framtida utformningen av läkemedelsförpackningar.

Under hösten 2003 och våren 2004 genomfördes tillsammans med About Design fem workshops med brukare för att testa olika förpackningar. Testpersonerna hade diagnostiserade sjukdomar eller skador som påverkar handfunktionen på grund av reumatiska eller neurologiska sjukdomar. Vanliga problem var smärta, muskelsvaghet, tremor, felställning, känselnedsättningar, enhänthet, spasticitet. Det som testades var att öppna en förpackning första och andra gången, dosera och därefter återförsluta. Vanliga förpackningar inom dagligvaruhandeln och läkemedelsförpackningar testades.

Till projektet knöts ett antal pilotföretag, Astra Zeneca, Cerbo, Emballator Växjöplast, TetraPak och Recip som testade sina produkter och därigenom medverkade till att metoden utvecklades. Företagen kunde testa olika typer av förpackningar eller prototyper och sedan i sin produktutveckling använda de kunskaper som testet gett. 
Utifrån vunna erfarenheter har Reumatikerförbundet genom Reuma Utveckling $A B$ tillsammans med Unicum,Nordisk Design För Alla Center och Spenshults reumatikersjukhus utarbetat en metod för att testa förpackningars hanterbarhet.

Metodutvecklingen har följts av en referensgrupp med representanter från Hjälpmedelsinstitutet, Konsumentverket, Läkemedelsverket, Läkemedelsförmånsnämnden, Apoteket, Läkemedelsindustriföreningen, DLF Dagligvaruleverantörers förbund och Hälsokostrådet.

Arbetet har skett med ekonomiskt stöd av Konsumentverket, Apoteket $\mathrm{AB}$ och Läkemedelsindustriföreningen samt genom egeninsats från Reumatikerförbundet. Reumatikerförbundet, Unicum och Spenshult har svarat för rekrytering och organisering av testerna.

Den metod som arbetats fram innebär att man gör hanterbarhetstester, inte Design för Alla-tester. Man tittar på alla hanteringsmoment hos en förpackning och hur människor upplever att utföra momenten:

- Hur lätt är det att greppa förpackningen?

- Hur lätt är det att öppna förpackningen första gången?

- Hur är det att ta önskad mängd ur förpackningen?

- Hur är det att återförsluta förpackningen?

- Hur lätt är det att öppna förpackningen andra gången?

- Hur är det att tömma förpackningen?

- Hur lätt är det att vika ihop förpackningen?

- Hur ser en totalbedömning av förpackningen ut?

Testpersoner, med nedsatt handfunktion, gör sin bedömning utifrån en skala från 1, som är extremt svårt, till 9 som är extremt lätt. 5 är varken lätt eller svårt för denna grupp. För att få omdömet Reumatikerförbundet godkänner måste produkten ligga på minst 5 på alla hanteringsmoment. För att bedömningen ska bli så rättvis som möjligt får alla i testgruppen testa en referensförpackning som tidigare har testats $i$ en stor grupp med 120 personer. En sådan förpackning finns med vid varje testtillfälle och får fungera som referensprodukt.

En produkt har fått omdömet Reumatikerförbundet rekommenderar, en plastburk tillverkad av Emballator Växjöplast. Den uppnådde resultatet 6,5 vid test. Omdömet Reumatikerförbundet rekommenderar används av kommunikationsskäl inte längre då det är svårt att etablera två nivåer vid marknadskommunikation. Fler företag, även livsmedelsföretag, testar och utvecklar idag produkter genom dessa tester.

Metoden är godkänd av Läkemedelsverket som "state of the art” när det gäller att värdera läkemedelsförpackningars tillgänglighet ur hanteringssynpunkt och få använda begreppet "reumatikeranpassad" i produktresumén. 


\subsubsection{Europeiskt standardiseringsarbete.}

Metoden utgör idag grund för ett europeiskt standardiseringsarbete för lättöppnade förpackningar med svenskt Europasekretariat. SIS/Tk/164/Ag 11 under den Europeiska tekniska kommittén CEN/TC 261.

Det innebär att alla berörda branschorganisationer, förpackningsindustrin och berörda varumärkesägare i Europa nu uppmärksammas på problematiken och med all sannolikhet bidrar till en för konsumenterna positiv utveckling.

En av de första uppgifterna blir att bestämma projektets omfattning och inriktning. Man ska besluta om vilka områden som ska ingå och hur avgränsningen ska göras mot bland annat krav på barnsäkerhet.

\subsubsection{Hjälpmedelsinventering}

Reumatikerförbundet har, med stöd av Hjälpmedelsinstitutet, genomfört en behovs- och probleminventering av vilka hjälpmedel som finns till försäljning på apotek och i "hjälpmedelsaffärer” för att öppna svåröppnade förpackningar vid nedsatt handfunktion. Det vanligaste hjälpmedlet är självöppnande saxar och tänger som finns i olika modeller. Undersökningen visar:

- att det finns en del lösningar på problemet

- att tillgängligheten på den öppna marknaden för sådana hjälpmedel är dålig

- att informationen till allmänheten om hjälpmedel är otillräcklig

- att brukare inte längre får denna typ av hjälpmedel från "samhället”

- att de flesta hjälpmedel skulle kunna få en mer attraktiv och tilltalande utformning.

\subsubsection{Massaktion för "Lättöppnade förpackningar"}

Under våren 2004 nominerades av Reumatikerförbundets lokala föreningar förpackningar som ansågs vara bäst respektive sämst. Fem dåliga och fem bra förpackningar valdes ut. Dessa presenterades för allmänheten vid aktioner på gator och torg och allmänheten fick rösta. 18000 röster avgavs. Äggkartongen valdes till bästa förpackning och glasburk med vakuum och lock till den sämsta.

\subsubsection{Folkrörelseprojektet "Lättöppnade förpackningar"}

Det var starten för en mobilisering av den allmänna opinionen med krav på mer lättöppnade förpackningar. Reumatikerförbundet etablerade ett samarbete med PRO Pensionärernas Riksorganisation, SPF Sveriges Pen- 
sionärsförbund, HSO Handikappförbundens samarbetsorgan och Sveriges Konsumenter (f.d. Sveriges Konsumentråd) och sökte pengar för projektet från Allmänna Arvsfonden. Projektet omfattar:

- TEMO-enkät angående förekomsten av problem hos befolkningen med att öppna förpackningar

- ett nätverk av 845 lokala kontaktpersoner/informatörer och 100 lokalgrupper

- en namninsamling för mer lättöppnade förpackningar, i juni 2007 omfattar den fler än 100000 namnunderskrifter.

- granskning av hälsokostförpackningar och val av bästa förpackning, priset delades ut den 21 oktober 2005

- regionala konferenser för de lokala grupperna

- undersökning av småbarnsföräldrars inställning till ett antal vanliga barnprodukter

- medverkan på mässor, seminarier och artiklar i fackpress

- folder som berättar om projektet på 8 språk: engelska, finska, spanska, turkiska, arabiska, persiska, bosniska och svenska

- undersökning hösten 2006 av Apotekets förpackningar för receptfri medicin och egenvårdsprodukter

- Handelns utredningsinstitut gjorde en enkätundersökning av dagligvaruföretags inställning till lättöppnade förpackningar hösten 2006

- våren 2007 genomfördes i samarbete med Astma och Allergiförbundet en enkät om förpackningar/produkter för astma- och allergimediciner

- våren 2007 genomfördes en undersökning av hårdplastförpackningar från Clas Ohlsons butiker

- "PÅVERKA! En handbok för konsumenter." utarbetas och trycks. Den är ett bra stöd för konsumentpåverkan generellt men hämtar exempel från projektet Lättöppnade Förpackningar.

\subsubsection{Samarbete med olika designutbildningar}

En tävling har genomförts bland designstudenter i Norden för att få fram ett tillgänglighetsmärke, Easy to Open. Syftet var att märket skulle kunna användas vid märkning av produkter som fått Reumatikerförbundet godkänner. Vinnare utsågs i december 2005. Märket har inte kommit att användas. Företag som har marknadsfört produkter som lättöppnade eller lätthanterliga har istället önskat använda begreppet "Godkänd av Reumatikerförbundet”.

På Konstfack har en kurs inom ämnet industridesign på temat Ta dig in genomförts. Resultatet presenterades i Kulturhuset under den tillgänglighetsvecka som HSO anordnade 2005. 
Andraårseleverna på Nackademins KY-utbildning har deltagit i ett projekt där det gällt att komma med förslag till förändringar av redan existerande förpackningar. De företag som deltagit har varit Göteborgs Kex, Axfood och Löfbergs Lila.

Studerande inom grafisk kommunikation på Forsbergs dagskola i grafisk design \& reklam i Stockholm har själva letat upp dåliga förpackningar, testat dem på handsvaga personer och därefter utarbetat förslag till förändringar. 6 olika förpackningar har utvecklats och gjorts mer tillgängliga. Exempel på produkter är mjölk, kaffe, batterier och pasta.

\subsubsection{Utbildning av testkonsulenter för tillgänglighetsvärdering}

En förstudie har genomförts finansierad av ESF-rådet i Halland. Syftet med den var att ta fram en utbildningsplan för konsulenter för värdering av förpackningar och andra produkter. Värderingen utgår från Design för Alla. Förstudien syftar till en ansökan om projektmedel för genomförande av utbildningen.

Utifrån erfarenheterna av förstudien genomfördes våren 2006 en testkonsulentutbildning med sju deltagare, om 5 månaders halvtidsstudier, på Spenshults sjukhus. Den var finansierad av ESF-rådet i Halland och länsarbetsnämnden. Därefter etablerades Testkonsulent- verksamheten på Spenshult.

\subsubsection{Aktieköp}

Aktier har inköpts i några företag. Representanter för Reumatikerförbundet har deltagit på bolagsstämmor och aktualliserat förpackningsproblematiken.

Mer om de svenska projekten finns på:

http://www.reumatikerforbundet.org/start.asp?sida $=5313$ 


\section{Måluppfyllelse}

Syftet med projektet var:

- att skapa bärare av arbetet/visionen i varje nordiskt land

- att utbyta kunskap och erfarenheter inom Norden

- att öka det nordiska samarbetet avseende utveckling av förpackningar

- att utgöra nordiskt forum för framtagande av riktlinjer/standarder för förpackningar med inriktning mot Design för Alla och som komplement till CEN/CENELEC Guide 6 (ISO/IEC Guide 71).

I varje nordiskt land finns bärare av visionen möjligen med undantag från Island. Genom reumatikerförbundens arbetsgrupp, den nordiska intressentgruppen/nätverket, konferensen den 5 maj 2006, samt utbyte av rapporter och information via webben har utbyte av kunskaper och erfarenheter skett.

Rollen som nordiskt forum för riktlinjer och standards har övergått till samarbetet inom Nordic Innovation Center -projektet och den europeiska standardiseringens ordinarie organ. Det pågår en utveckling av både metoder och förpackningar i Norden och här kunde det ha utvecklats en ännu större samverkan.

Den långsiktiga målsättningen har genom standardiseringsarbetet goda förutsättningar att uppnås. Det är upp till företagen att nu ta vara på konsumentintresset och de konkurrensfördelar som finns i att utveckla och marknadsföra lätthanterliga förpackningar.

\subsection{Fortsatt samarbete}

Som framgått ovan fortsätter organisationerna sitt påverkansarbete i de olika nordiska länderna. Samarbetet kommer också att fortsätta gemensamt inom Norden, dels inom NIC-projektet, dels mellan reumatikerorganisationerna och i den nordiska intressentgruppen, men nu inom ramen för varje organisations ekonomiska förutsättningar. En översättning till alla nordiska språk av "PÅVERKA! - En handbok för konsumenter" bör eftersträvas så att vunna erfarenheter kan tas till vara på bästa sätt i det lokala arbetet i varje land. 



\section{Arbetet utvidgas}

\subsection{Etablera brukarpaneler utifrån visionen Design för}

Alla

På uppdrag av HSO och med ekonomiskt stöd från Konsumentverket och Hjälpmedelsinstitutet har Reumatikerförbundet genomfört en förstudie för att ta fram underlag och förutsättningar för att etablera allsidigt sammansatta brukarpaneler. Dessa ska medverka i produktutvecklingen genom testning av varor och tjänster, och ska kunna företräda ett Design för Alla-perspektiv.

Studien, som omfattade 100 företag inom förpackningsbranschen, hemelektronik och telekom, visade att många företag inte alls testar med hänsyn till användarvänlighet. I de fall tester görs, sker det ofta på den egna personalen och i liten skala. Det är ett fåtal av företagen som känner till att det finns möjlighet att engagera testpersoner och brukarpaneler vid testning.

I studien ingår också intervjuer med företag, myndigheter och organisationer för att undersöka deras intresse för testning av sina webbsidor utifrån användbarhet. Resultatet visar att det är en ny fråga, men att det finns ett intresse.

En projektansökan till Allmänna Arvsfonden för att utveckla konceptet med Brukarpaneler utarbetas våren 2007 av HSO, Handikappförbundens Samarbetsorgan med Hjälpmedelsinstitutet och Konsumentverket som samarbetspartner. 